布施鉄治編著

\title{
『倉敷・水島/日本資本主義の展開と都市社会一繊維工業段階 から重化学工業段階へ：社会構造と生活様式变動の論理一』
}

中田実

布施鉄治教授をリーダーとする研究グループの 10 年にわたる共同研究の成果が, 炭都・張についての大著にひき続くさらなる大著として刊行された。その壮大な エネルギーと見事な集中力に，ただ目を見張るばかりである。まずはこの壮図に敬 意を表するものである。そして, これだけの大著にもかかわらず（あるいは，これ だけ書き込んだために)，なお一層知りたい点がでてくる思いがあり，われわれが 対象とする現実の社会が限りない広さと深さをもつことに，あらためて驚嘆を禁じ えなかった。

さて，この大著について，著者たちの意図をふまえて正確に読み取り，その上で 論評を加えることは至難の技であり, とうてい私のなしうるところではない。大著 なるが故に，編著者による内容の要約が，第 1 部第 1 章，および「総括」で丁寧に 行われていること（とはいえ，やはり索引をつけることをわが国でももっと慣例化 すべきであるとの思いは禁じえない)，また，個々の内容についてここで言及する ことが不可能であることから，本稿では，本書の目的と方法，構成等の概要を紹介 した上で，主として地域社会論に偏る私の関心に引きつけて，いくつかの点につい て意見を述べ，ご教示をいただければと考えている。なお，以下の検討には，名古 屋大学大学院文学研究科社会学専攻の院生諸君にも加わってもらった。

\section{1 研究の目的と方法}

まず, 北大布施グループの研究経過と本書の位置を見ておこう。本書は, 著者た ちの都市研究としては, 炭都・夕張についての研究（その成果は『地域産業変動と 階級・階層一一炭都・夕張/労働者の生産・労働一一生活史・誌』御茶の水書房, 1982 年）につぐもので, 前者の対象地が「単一産業都市」で, しかも高度経済成 長期にわが国のエネルギー政策の転換によってスクラップ化されていく都市・夕張 であったのにたいし，今回の研究対象地は「複合産業都市」で，同期の高度成長の リーディング産業であった重化学工業がビルドされていく都市・倉敷を取り上げて いる点で対照的である。ついでにいえば，同グループは現在，東京都内の「下町」 の調査を進めており, 都市住民諸階層の生活に視点を置いて「都市の変動, 発展と は何か」を追求しておられることも，紹介されている。

さて，1982 年より開始された本研究は，「戦後日本資本主義の強蓄積を具体的に 担うべく，国家と資本による政策的・戦略的拠点として形成された，現代日本にお 
ける典型的な重化学工業都市」倉敷（88 頁）の都市社会変動を取り上げ，「日本資 本主義の展開と都市社会」形成を「生産・労働一生活過程分析」の手法を機軸とし, 「社会機構一社会構造分析」と「運動, 組織形成, 再生過程分析」の手法を用いて 解明したものである。それは, 地域産業の業種転換が地域の階級・階層構造を変化 させ，さらに地域社会の構造と住民の生活様式を巻き込んで変動させていく過程を， 「地域 (都市) 社会の形成・発展の論理」として取り出し, その日本的特質を把握す るとともに，それを通じて労働者の主体的内実すなわち価值志向の変容の実態・特 質をさぐろうとしている。それは「市民各階層の生産・労働一生活史を正確にとり おさえ」，それを「彼ら自身の生活の内在論理に沿うて理解すること」を目指して おり，「市民層の生活の立場から，この変動しつつある倉敷・水島地域社会の総体を 把握する」ものであると著者たちはいう。それはまた, 瀻維工業段階から重化学工 業段階への「段階移行の社会学的意味」を解明することでもある。

こうした課題にとって, 対象地域倉敷がもつ特質を見ると, 本市は瀻維工業段階 から重化学工業段階へという産業の「業種転換」が一つの地域の中で観察できる典 型的な地域であるとともに, 農漁業地区, 地場産業地区, 観光地区等, 多様な特質 を持つ地区を含んでおり，都市形成過程が総合的に追跡できるところである。また， 合併により成立した新「行政都市」とそこに内包される旧「自然都市」との関係を 見ることもできる。

研究方法としては, 行政市倉敷の内部で多様な特性を示す各地域から「典型的」 な企業等の事業主体を選んで, 職場の構造, 従業員個人および家の生業・生活史, 町内会の構成と展開, 労働・住民運動等を克明に「追いあげる」とともに, 全市的 規模での行財政, 政治過程, 市民意識の調查を行っている。そして, 新倉敷市の四 極構造をなす旧地区（倉敷・児島・玉島・水島）および農漁村地区のそれぞれの研 究の上に, 地区相互の比較および新市としての各地区の相互連関の研究と, 何重も の研究の積み上げと統合が目指されている。

\section{2 本書の構成}

本書は, はしがき, 全 9 部, 総括からなる全 3 分冊, 1162 頁の大作で, 布施教 授ほか 13 名の執筆者, 多くの学生, 院生, 調査対象者の協力の産物である。その 構成を簡単に示しておこう。以下, 部名は本書のもの,〔 〕内は, その内容を私 が補足したものである。

第 1 部 産業都市社会変動と生活様式分析の論理〔研究主題と分析論理, 本書の 構成および対象地域の概況]

第 2 部 水島重化学コンビナートの造成／新たな職場生活の創造と水島地区社会 の再編過程〔A 自工, 零細事業体, 町内会, 労働組合〕

第 3 部 水島コンビナート— $\mathrm{A}$ 自工・下請ネットの地域社会への根づきと地域 社会の変動過程

第 4 部＼cjkstart瀻維産業都市・倉敷社会の構造変動〔 $\mathrm{K}$ 紡績, 観光拠点, 都市開発〕 
第 5 部 瀻維・縫製都市・児島社会の構造変動

第 6 部 地場産業都市・玉島社会の構造変動〔地場機械・食品企業〕

第 7 部 農村 (茶屋町)・漁村 (下津井) 社会の構造変動

第 8 部 倉敷市における階級・階層構造と生活様式変動の論理

第 9 部 地域社会変動の諸局面／運動と政治と行政

総括 日本資本主義の発展と都市地域社会の構造的発展における日本的特質

\section{3 本書の成果と特徵}

以上のように, 本書は, 「日本資本主義の発展に伴う繊維工業段階から重化学工 業段階への発展の中での地域社会変動」に焦点をあてる。しかし，ここでいう地域 社会は「個別地域社会学の立場」に特化されたものではない。人間が生きる場とし ての地域は, 生産・労働一生活が営まれ, 変容を重ねている場である。それの把握 のためには, 職場における「生産・労働」の変化, それと連動する家族関係の変化 を含む生活様式の変化を軸に多様な社会諸事象を構造化し, それをとおして「地域 社会の移行の実体」に総合的に迫ることが必要である。その意味で,「今日の地域 社会学は，……総合社会学としての性格をもつべきもの」(38 頁) なのである。 著者たちの対象地域の社会的諸現象への目配りの広さと貪欲さ, したがってまた本 書の内容の豊富さは, こうした研究方針に由来するものである。そのために, 本書 は社会学の広い領域にたいして資料と研究視点を提供しうるものとなっており,さ まざまな読み取りを可能にする業績となっている。

個別の関心にもとづく読みとりは各読者に委ねるとして, まず本研究の目的に照 らして成果と考えられる点を項目にまとめてみると，以下のようになろう。

(1) 繊維工業段階から重化学工業段階への移行下での地域社会の変動の総体の解 明——特定地区の単なるモノグラフを越えた現代日本社会の構造・変動の典型的 特質の剔出。出稼ぎ労働者の街から定住労㗢者の街への転換を軸にしつつ, 産業 の構造転換が重層的過程をとること，およびそれが産業・企業間でも，企業内の 労働者の職種別, さらには地域住民層間でも, 階級・階層的構造をとり, またそ れらの間の変動でもあることの確認。

（2）地場産業から重化学工業, 観光・サービス業にいたる各種企業の歴史的, 階 層的構造とその展開，下請け網を含むそれらの地域的ネットワークの解明。

（3）各企業内での労働者の労働過程, 労働生活と意識の連関（職場社会の文化構 造）の, 多様な職種，世代等に即しての具体的でリアルな解明。

（4）各企業内での労働者の組織と運動の, 労働者の生活と意識と関連させての解 明。「下からの QC」とそれを解体させる「上からの QC」活動の現実的な意味の 解明。

（5）住民が現在の就労形態をとるにいたった家族史的背景の追跡と, 現在の家族 構造, 家族意識の変化。長時間労働とセットになった家族多就業構造下での生活 防衛と女性にかかる過重な負担, それにもかかわらずこの状況を踏み台にして積 
極的に生きようとする女性の社会的意識の解明。

（6）家族あるいは個々の家族員とくに女性の地域社会とのかかわり，地域社会の 組織（町内会や講組織, 各種目的別住民組織）の構造と機能, それらの変動の解 明。

（7）長時間労働が生活の基礎条件となっていることによる社会関係発展の阻害状 況の解明, 近隣関係の希薄化と家族・血縁ネットワークへの収斂，この関係をも たないもの（例えば単身老人）の孤立化の析出, これらの点での階級・階層的意 味の再確認。

（8）地域における市民運動，とくにコンビナート進出にともなう激しい公害にた いする反対運動の展開と，この経験が地域社会に残した痕跡の解明。

（9）市の行政・財政・開発政策を国や県の政策との関連のもとに解明するととも に，地域政治，地域権力構造を分析し，「行政都市」を統合するためには新しい 文化を創造する必要があることの指摘。

（10）都市地域社会の構造と市民意識について，市民の価值が「人間化，生活化， 個性化」(1127 頁) へと構造的に変容しているとはいえ, 生活防衛に追われて生 活創造の段階に至っていないことをふまえての,「『家』的社会」から「市民社 会」への展開の状況と限界，そこでの日本的特質の解明。

\section{4 本研究をめぐる論点}

ここでは触れることができなかった点も含めて豊富な内容をもつ本書ではあるが, なお以下の諸点について議論を深め，ご教示がえられれば幸いである。

(1) 地域社会の捉え方

本研究が総合社会学の立場に立つものであることは先にふれた。それ自体は妥当 な方法であり，この立場に立つ地域社会学者も少なくない。これを広義の地域社会 学というならば, しかし，個別社会学としての地域社会学つまり狭義の地域社会学 も存在すると思われる（本書に列挙された個別社会学の中には，地域社会学の名は ないが)。私見によれば，後者は「土地の共同」を契機とする（地縁で結ばれた） 社会関係の構造・機能とその変動を対象とするもので，それはその地域の産業（職 場）の状況および家族の生活様式に規定されながらも，それらの変動からだけでは 説明できない独自の領域（本書で町内会について「住民の地域生活を基礎にした組 織」(950 頁) と性格づけられているのも，この意味であろう）をなすものと考え られる。本書では，地域社会組織としては，「職場↔地域社会」が「二つの拠点」 （39 頁）として基軸にすえられている。この場合の「地域社会」は狭義のそれを指 すものと思われ，実体としては「近隣」や講組織，町内会と各種目的別組織，住民 運動組織等が取りあげられ分析されているが, これらの諸組織の位置づけを含めて 狭義の「地域社会」の特質をどのように押さえ, その研究を総合社会学のなかにど う位置づけるかも，地域研究の課題であろう。そのことによって，例えば町内会の 機能について，住民の参加の態度が決め手という，実践的に妥当ではあるが対象の 
性格規定を欠く議論（その結果，地域社会の現状についてはきわめて悲観的評価に 止まる）を克服することができるとともに，地域社会を担う住民の主体的力量の形 成をどこに見出すかについての検討が可能になるのではないかと思われるが，いか がであろうか。

なお，本市の町内会について，まとめの部分で，「公害反対の住民運動がもりあ がりの際，市では町内会の認知を取り消し」た（1115頁）というきわめて重大な 指摘がなされている。児島地区についての記述のなかで「自治振興委員会」にたい し「解散命令」(1972 年) が出されたとの指摘があり，このことを指すようである が，その翌年に自治連合会が発足している(714 頁)。行政が町内会を利用し続け ているもとで町内会は「市行政が『認知』した組織になっていない」(971頁) と はどんな意味か, これにたいする町内会側の対応や変化はどうだったか等を含めて, 本文でぜひとも言及してほしかった。また，次項で問題とする点ともかかわらせて， 行政によるコミュニティ施策展開の意味（「移行」との関係）についても（断片的 な言及に止めずに)，触れてほしかった。

（2）日本資本主義の発展にともなう社会構造転換の把握について

本書は, 地域社会とそこで見られる資本主義の発展に即しながら, 日本社会の構 造把握をめざすものであった。ところで, 地域社会が繊維工業段階から重化学工学 段階へ発展的に移行することは，「経済レベルでの変動のみではなく，……社会 自体の構造変化，そして，労働主体者の価值志向の主体的変容」をもたらす。「社 会自体の構造変化」とは，「家』的社会から『市民社会』へ向けて，全体としての 社会構造それ自体が変容する」(1124 頁) こととされる。しかし他方で，上記の工 業段階間の発展的な移行は「一元的」な交替でなく, 農業から工業への展開までを も含む「二元的，重層的プロセス」として現れる。つまり，現時点では，両工業は 地域内で，農漁業とともに分業的に併存しているのであり，そうであれば，これに よる地域社会の構造変容も一元的に起こることはありえないことになろう。

ここではまず，繊維工業段階から重化学工業段階への発展的な移行を，全国的， したがって歴史的な日本資本主義の発展過程として押さえておくこと，ついでそれ が重化学工業段階に入って以降の時期に瀻維工業地域に重化学工業が導入されてく ることで生ずる変化とを区別することができるであろう。現実の移行が生み出す 「社会自体の変容」はこの両者の変化にもとづくものであるが，さらにその背景に は，階級の視点を基礎とする日本資本主義の経済的社会構成体の移行をも視野に収 めるものであったはずである。そうであれば,・「家』的社会から『市民社会』へ向 けて, 全体としての社会構造それ自体が変容」する際の,「市民社会」の展開の諸 段階とそれぞれの過渡的形態ないし内容が問われることになろう。「市民社会」と いうきわめて抽象的な概念でこれらの変容を説明することには無理があるのではな かろうか。

上記ともかかわって,「移行過程」が社会構成体のそれから産業段階のそれ（業 種転換）に変化ないし具体化された（もちろん，社会構成体の移行も地平ににらみ 
つつではあろうが）ことで，その主体（例えば労働組合）の位置と意味が変化して くるのではないか。この点での理論的見通し，例えば，重化学工業段階での労働組 合組織化の独自の内容，その普遍的抢よび日本的限界の問題があろう。「移行」を 問題にされるだけに，「市民社会」概念の一層の明確化が望まれる。

（3）水島コンビナート建設にともなう地域社会変動——とくにムラ的社会の変容 をめぐって——

コンビナートの創設という大きなインパクトによる地域社会, とりわけ農漁村の 変動のすさまじさは，特産で高収益をあげてきたい草の生産が，公害によって壊滅 させられたことに象徵的に示されている。福武理論のなかでフラットな社会構造を もつ講組結合のムラとされた当地方で, 農村では農地売却の有無と兼業種別による 新たな階層分化, 漁村では漁業「補償の恩恵」の階層差による格差の拡大が進んで いる。それでもムラは「完全に解体しつくした段階には至っていない」(829頁) が, この変化を捉える上で本質的なことは, 「農業生産と農村社会を発展させる担 い手」のあり方であり，それが脆弱化している現在，「農民存在のあり方そのもの を含めて根本的に変質」を迫られているという。

生産環境の悪化のもとで, 補償により生産設備はむしろ改善強化しているという 矛盾を抱える農漁業については, これを発展させる「担い手」を見出すことができ るか, あるいはムラの完全な解体は避けられないのか。このことも, 現在農漁業を 営む人びとのあり方の内に探らなければならない。兼業であれ農業を継続する志向 性が強いのは, 生産・労働への関心より「土地に対する執着心」(831頁) のためだ けなのか, そしてまた，農漁業生産を継続するためにも，非農家を含む近隣関係の 維持が重要となっていることはないのか（それとなお残存する「共同体的・ムラ的 社会関係」(720 頁) をどう評価するか) 等は, 他方での「沖先漁業」といった用 語とともにいささか気になる点ではある。

複合産業都市の総合的解明のために設定された地域一企業体一職場一家族一町内 会といった各「節」についての詳細な事例研究の対象者および事例数の決定につい ては, 典型事例研究法というべき方法がとられている。ききとりの内容はそれぞれ 大変興味深く, またこの研究の真骨頂として調査の苦労をしのんで余りあるが，そ の結果は対象の分析的理解のために限定されたものである点はふまえておかなけれ ばならない。

以上，あまりにも限定した取り上げ方になってしまったことをお詫びするととも に, 学ぶことの多い豊かな内容をもつ本書がより多面的に研究されることを期待し ている。

追記 本稿は 1993 年 1 月に編集委員会に提出され，同年 2 月 1 日に受理された。当時すでにご 病気とうかがっていた布施教授は，95 年 6 月に逝去をされた。本稿の表理は変えていないが， 哀悼の意を表するものである。

(名古屋大学教授) 